\title{
EDUKASI DAN DETEKSI DINI ANEMIA REMAJA PUTRI DI PANCUR BATU KABUPATEN DELI SERDANG
}

\author{
Yulina Dwi Hastuty ${ }^{1}$, Dodoh Khodijah ${ }^{2}$, Yusrawati Hasibuan ${ }^{3}$ \\ Coreponding author: yulinadwihastuty@gmail.com \\ 1,2,3 Jurusan Kebidanan, Poltekkes Kemenkes Medan, Indonesia
}

Genesis Naskah: Submitted: 27-10-2021, Revised: 24-11-2021, Accepted: 29-11-2021

\begin{abstract}
Abstrak
Anemia sampai saat ini masih menjadi masalah kesehatan yang sering dialami oleh seorang wanita. Remaja putri merupakan salah satu kelompok yang rawan terkena anemia, terkait body image juga karena proses menstruasi. Dampak anemia pada remaja cukup besar bahkan dapat memengaruhi proses tumbuh kembang dan kecerdasan. Di Indonesia prevalensi kejadian anemia remaja cukup tinggi mencapai 57,1\%, untuk kabupaten Deli Serdang kasusu anemia mencapai $71 \%$ di pedesaaan. Pemerintah telah melakukan berbagai upaya guna mencegah terjadinya anemia pada remaja namun belum mendapat hasil yang maksimal. Pengetahuan dan pemahaman dari setiap individu diperlukan agar anemia dapat diatasi. Tujuan kegiatan pengabdian masyakat ini untuk mendeteksi dan meningkatkan pemahaman siswi tentang anemia. Metode yang digunakan dalam kegiatan pengabdian masyarakat ini melalui kegiatan penyuluhan karena metode ini dapat dilakukan dengan cepat dan mudah dipahami serta pemeriksaan kadar Haemoglobin $(\mathrm{Hb})$ sebagai deteksi dini.pada siswi yang ada di SMA Negeri 1 Pancur Batu Deli Serdang Sumatera Utara karena kasus anemia masih ditemukan di sekolah ini. Siswi yang mengikuti penyuluhan adalah siswi kelas X sampai XII yang hadir di sekolah pada saat kegiatan dilaksanakan sebanyak 73 orang dan yang bersedia diperiksa kadar Hb nya sebanyak 57 orang. Hasil yang didapat dari kegiatan ini adalah terdeteksinya kadar $\mathrm{Hb}$ siswi dan bertambahnya pengetahuan siswi setelah diberikan penyuluhan. Hal ini terlihat dari peningkatan rata-rata hasil pre test dan post test dari 5,68 menjadi 11,05, berdasarkan hasil pemeriksaan kadar Hb didapati adanya siswi yang anemia sebanyak 17 orang $(29,8 \%)$. Dengan adanya kegiatan pengabdian masyarakat ini anemia pada remaja khususnya siswi di SMA Negeri 1 Pancur Batu dapat terdeteksi secara dini, selain itu upaya pencegahan dapat dilakukan dengan adanya peningkatan pengetahuan baik terhadap siswi maupun masyarakat sekitar.
\end{abstract}

Kata Kunci: Anemia, Remaja, Deteksi Dini, Peyuluhan.

\section{EDUCATION AND EARLY DETECTION OF ADOLESCENT ANEMIA IN PANCUR BATU, DELI SERDANG REGENCY}

\begin{abstract}
Anemia is still a health problem that is often experienced by a woman. Adolescent girls are one of the groups that are prone to anemia, related to body image as well as due to the menstrual process. The impact of anemia on adolescents is quite large and can even affect the process of growth and development and intelligence. In Indonesia, the prevalence of anemia in adolescents is quite high, reaching $57.1 \%$, for Deli Serdang district, anemia cases reached $71 \%$ in rural areas. The government has made various efforts to prevent the occurrence of anemia in adolescents but have not received maximum results. Knowledge and understanding of each individual is needed so that anemia can be overcome. The purpose of this community service activity is to detect and improve students' understanding of anemia. The method used in this community service activity is through outreach activities because this method can be done quickly and easily and is also checked for hemoglobin (Hb) levels as an early detection. found in this school. The students who took part in the counseling were 73 students who were present at the school at the time the activity was being held and 57 people who were willing to have their $\mathrm{Hb}$ levels checked. The results obtained from this activity were the detection of Hb levels of students and increased knowledge of students after being given counseling. This can be seen from the increase in the average pre-test and post-test results from 5.68 to 11.05 , based on the results of the Hb level examination, 17 students were found to be anemic $(29.8 \%)$. With this community service activity, anemia in adolescents, especially
\end{abstract}


students at SMA Negeri 1 Pancur Batu, can be detected early, besides that prevention efforts can be carried out by increasing knowledge of both students and the surrounding community.

\section{Keywords: Anemia, Adolescents, Early Detection, Counseling}

\section{Pendahuluan}

Masa remaja merupakan masa peralihan antara masa kehidupan anak-anak dan masa kehidupan orang dewasa yang ditandai dengan pertumbuhan dan perkembangan biologis dan psikologis (Hidayati \& Farid, 2016). Perubahan fisik karena pertumbuhan yang terjadi akan memengaruhi status kesehatan dan gizinya. Ketidakseimbangan antara asupan kebutuhan atau kecukupan akan menimbulkan masalah gizi, baik itu berupa masalah gizi lebih maupun gizi kurang. Masalah gizi yang biasa dijumpai pada remaja antara lain, anemia, obesitas, kekurangan energi kronis atau KEK, perilaku makan menyimpang seperti anoreksia nervosa dan bulimia (Masthalina et al., 2015).

Anemia merupakan penurunan kadar hemoglobin, eritrosit, dan hematokrit sehingga jumlah eritrosit dan/atau kadar $\mathrm{Hb}$ yang beredar tidak dapat memenuhi fungsinya untuk menyediakan oksigen bagi jaringan tubuh (Hoffbrand V, 2013). Kadar Hb yang rendah merupakan salah satu masalah kesehatan yang sering dialami oleh seorang wanita tidak terkecuali remaja. Batas kadar $\mathrm{Hb}$ remaja putri untuk mendiagnosis anemia yaitu apabila kadar Hb kurang dari 12 gr/dl (WHO, 2015).

Remaja putri merupakan salah satu kelompok yang rawan menderita anemia. Remaja putri berisiko lebih tinggi terkena anemia dibandingkan dengan remaja laki-laki karena remaja perempuan setiap bulan mengalami menstruasi dan memiliki kebiasaan makan yang salah, hal ini terjadi karena para remaja putri ingin langsing untuk menjaga penampilannya sehingga mereka berdiet dan mengurangi makan, akan tetapi diet yang dijalankan merupakan diet yang tidak seimbang dengan kebutuhan tubuh sehingga dapat menyebabkan tubuh kekurangan zat-zat penting seperti zat besi (Crowe, 2012).

Anemia yang terjadi pada remaja dapat membawa dampak yang tidak baik seperti menurunnya kesehatan reproduksi, perkembangan motorik, mental, kecerdasan terhambat, menurunnya prestasi belajar, tingkat kebugaran menurun, dan tidak tercapainya tinggi badan maksimal (Adriani \& Wirjatmadi, 2016). Kehamilan pada usia remaja juga dapat meningkatkan resiko terhadap kematian ibu, bayi, atau risiko melahirkan bayi dengan berat bayi lahir rendah (Crowe, 2012).

Besarnya dampak yang diakibatkan anemia pada remaja, menjadi dasar untuk dilakukannya tindakan guna mencegah kejadian anemia defisiensi besi, karena itu remaja puteri perlu dibekali dengan pengetahuan tentang anemia defisiensi besi.

Penyebab terjadinya anemia dapat diakibatkan faktor gizi dan non gizi. Faktor gizi terkait dengan defisiensi protein, vitamin, dan mineral, sedangkan faktor non gizi terkait penyakit infeksi. Protein berperan dalam proses pembentukan hemoglobin, ketika tubuh kekurangan protein dalam jangka waktu lama pembentukan sel darah merah dapat terganggu dan ini yang menyebabkan timbul gejala anemia. Penyebab utama anemia gizi di Indonesia adalah asupan zat besi $(\mathrm{Fe})$ yang rendah. Anemia gizi 
besi dapat menyebabkan penurunan kemampuan fisik, produktivitas kerja, dan kemampuan berpikir. Selain itu, anemia gizi juga dapat menyebabkan penurunan antibody sehingga mudah sakit karena terserang infeksi dan dapat menimbulkan kelelahan, badan lemah, penurunan kapasitas/kemampuan (Utama et al., 2013).

Status zat besi di dalam tubuh manusia tergantung pada penyerapan zat besi tersebut. Hal -hal yang dapat memengaruhi penyerapan Fe diantaranya adalah enhancer dan inhibitor. Enhancer berperan besar terhadap penyerapan zat besi sedangkan inhibitor menghambat penyerapan zat besi di dalam tubuh. Enhancer zat besi diantaranya vitamin $\mathrm{C}$ dan vitamin $\mathrm{A}$. Vitamin $C$ sebagai enhancer karena vitamin $C$ membantu penyerapan besi non heme dengan merubah bentuk feri menjadi fero yang mudah diserap (Ayu Dwi Putri Rusman, 2018). Sedangkan interaksi Vitamin A dan karoten dapat membentuk suatu kompleks dengan besi untuk membuatnya tetap larut dalam lumen usus dan mencegah efek penghambat dari fitat dan polifenol pada absorpsi besi (Permaesih et al., 2011).

Data Riset Kesehatan Dasar (Riskesdas, 2018) menunjukkan adanya peningkatan anemia pada remaja putri dari 37,1\% pada Riskedas 2013 menjadi 48,9\% pada Riskesdas 2018, dengan proporsi anemia ada di kelompok umur 15-24 tahun dan 25-34 tahun. Data yang didapat dipedesaan kabupaten Deli Serdang menunjukkan kasus anemia mencapai $71 \%$. Hal ini jelas menunjukkan bahwa kasus anemia pada remaja tidak dapat dianggap ringan apalagi kesehatan remaja sangat menentukan keberhasilan pembangunan kesehatan, terutama dalam upaya mencetak kualitas generasi penerus bangsa di masa depan (Kemenkes, 2018).

Upaya pencegahan dan penanggulangan anemia yang telah dilakukan selama ini lebih banyak ditujukan pada ibu hamil, sedangkan remaja putri secara dini belum terlalu diperhatikan. Mengingat bahwa penyerapan $\mathrm{Fe}$ dipengaruhi oleh inhibitor dan enhancer yang mana hal tersebut belum banyak diketahui oleh remaja (Utama et al., (2013); Permaesih et al., (2011) ; Astuty \& Khodijah, (2018). Bentuk edukasi berupa penyuluhan tentang cara deteksi dini dan pencegahan anemia pada remaja perlu dilakukan, sehingga anemia dapat dicegah dan dampak yang ditimbulkan dapat diturunkan. Tujuan kegiatan pengabdian masyarakat ini adalah memberikan edukasi kepada remaja tentang anemia dan bahayanya juga melakukan deteksi dini anemia pada siswi yang ada di SMAN 1 Pancur Batu Kabupaten Deli Serdang.

\section{Metode Pelaksanaan}

Metode yang digunakan dalam pengabdian masyarakat ini meliputi kegiatan pre-test dan post-test, penyuluhan, pemeriksaan $\mathrm{Hb}$ dan pemberian tablet $\mathrm{Fe}$ bagi yang terdeteksi anemia.

Pretest dilakukan pada saat pertama sekali tatap muka di ruangan dengan siswi yang menjadi peserta kegiatan. Peserta yang ikut pada kegiatan pengabdian masyarakat ini adalah siswi SMA yang ada di SMA N 1 Pancur Batu dari kelas X sampai kelas XII yang hadir kesekolah 
pada saat kegiatan. Jumlah soal yang diuji pada saat pretes sebanyak 15 soal dengan bentuk multiple choice. Setelah kegiatan penyuluhan maka dilakukan post test untuk melihat sejauh mana keberhasilan penyuluhan yang diberikan.

Penyuluhan dilakukan dengan terlebih dahulu menanamkan prinsip bahwa deteksi dini anemia adalah hal yang sangat penting untuk diketahui oleh setiap wanita baik remaja maupun usia dewasa. Penyuluhan dilakukan satu kali setelah pre test dengan menggunakan alat bantu audiovisual berupa video dan gambar-gambar yang menampilkan bagaimana cara deteksi dini anemia. Peserta juga diberikan leaflet.

Pemeriksaan $\mathrm{Hb}$ kepada peserta kegiatan dilakukan setelah kegiatan penyuluhan dengan menggunakan digital Easy Touch dan pemberian tablet $\mathrm{Fe}$ yang dikombinasi dengan vitamin kepada peserta yang setelah diperiksa terdeteksi anemia. Setelah pemeriksaan kadar Hb dilakukan post test.

\section{Hasil dan Pembahasan}

Hasil yang didapat dari nilai pre test pada siswi tentang anemia pada remaja masih rendah karena masih ada siswi yang memiliki skor rendah, ini terlihat dari jumlah siswi yang mendapat skor 4 paling banyak mencapai 27.8 $\%$ sedangkan siswi yang mendapat skor 9 hanya 8 orang $(10,9 \%)$ dengan rentang skor 4 9. Nilai rata-rata yang diperoleh siswi berada pada angka yaitu 5,68. Hal ini juga menunjukkan bahwa pengetahuan siswi tentang anemia remaja masih belum maksimal.
Tabel 1. Nilai Pretest Pengetahuan Siswi tentang Anemia pada Remaja

\begin{tabular}{lll}
\hline Skor Pretest & $\mathbf{n}$ & \% \\
\hline 4 & 20 & 27.8 \\
\hline 5 & 19 & 26.4 \\
\hline 6 & 16 & 22.2 \\
\hline 7 & 8 & 11.1 \\
\hline 8 & 2 & 2.8 \\
\hline Total & 73 & 100 \\
\hline Rata-rata & 5,68 & \\
\hline
\end{tabular}

Tabel 1 menunjukkan mayoritas pengetahuan siswi masih rendah tentang anemia pada remaja.

Tabel 2. Nilai Post test Pengetahuan Siswi tentang Anemia pada Remaja

\begin{tabular}{lll}
\hline Skor Post test & $\mathbf{n}$ & $\mathbf{\%}$ \\
\hline 9 & 10 & 13.6 \\
\hline 10 & 21 & 28.7 \\
\hline 11 & 15 & 20.5 \\
\hline 12 & 12 & 16.4 \\
\hline 13 & 12 & 16.4 \\
\hline 14 & 3 & 4.1 \\
\hline Total & $\mathbf{7 3}$ & $\mathbf{1 0 0}$ \\
\hline Rata-rata & $\mathbf{1 1 . 0 5}$ & \\
\hline
\end{tabular}

Tabel 2 menunjukkan pengetahuan siswi tentang anemia pada remaja mengalami peningkatan dengan rentang skor 9-14 dan mayoritas berada pada skor 10 . 
Tabel 3. Hasil Pemeriksaan Kadar Hb pada Siswi di SMA 1 Pancur Batu

\begin{tabular}{lcc}
\hline \multicolumn{1}{c}{ Variabel } & n & \% \\
\hline Anemia & 17 & 29,8 \\
Tidak anemia & 40 & 70,2 \\
\hline Total & 57 & 100 \\
\hline
\end{tabular}

Tabel 3 di atas menunjukkan bahwa setelah dilakukan pemeriksaan kadar $\mathrm{Hb}$, ditemukan remaja putri yang menderita anemia sebesar $29,8 \%$.

Berdasarkan hasil pre test dan post test yang dilakukan didapatkan hasil adanya peningkatan rata-rata skor pengetahuan siswi. Sebelum di berikan penyuluhan skor rata-rata adalah 5,68 sedangkan setelah diberikan penyuluhan didapat peningkatan skor rata-rata menjadi 11,05. Dengan adanya peningkatan nilai rerata tersebut menunjukkan bahwa pemberian penyuluhan tentang anemia pada remaja memiliki manfaat yang cukup besar terhadap perubahan pengetahuan peserta penyuluhan. Secara umum angka kejadian anemia dapat diantisipasi dengan berbagai cara mulai dari promotif, preventif dan kuratif. Upaya preventif dan kuratif tak akan berjalan lancar tanpa usaha promotif. Penyuluhan dipilih sebagai salah satu pilar utama dalam tindakan promotif untuk meningkatkan pengetahuan (Maulana, n.d.). Beberapa peneliti mendapati bahwa pengetahuan seseorang memiliki hubungan dengan terjadinya anemia (Purbadewi, dkk, 2013, Listiyana A, 2016, Putri KM, 2018, Rusman A, 2018).

Pengetahuan yang baik berkaitan dengan sikap yang dapat mengarah pada pencegahan anemia. Hasil kegiatan ini sejalan dengan penelitian Egryani et al., (2017) yang mendapati bahwa penyuluhan dapat meningkatkan pengetahuan pada ibu hamil tentang anemia. Pengetahuan yang meningkat setelah diberikan edukasi berupa penyuluhan menunjukkan bahwa informasi yang selama ini kurang dapat menjangkau siswi di Kecamatan Pancur Batu dapat diatasi dengan pemberian penyuluhan melalui kegiatan pengabdian masyarakat ini, disamping itu keingintahuan siswi terhadap halhal yang berkaitan dengan anemia pada remaja cukup besar terbukti selama penyuluhan siswi sangat aktif memberikan pertanyaan seputar anemia pada remaja sehingga dengan diberikannya penyuluhan informasi atau pesanpesan kesehatan mengenai anemia dapat diterima dengan baik.

Pada kegiatan ini juga masih terdapat tingkat pengetahuan tentang anemia yang rendah, masih ada siswi yang mendapat skor 9. Hal ini bisa disebabkan oleh beberapa hal diantaranya adalah faktor pengalaman yang memengaruhi pengetahuan seseorang dan tergantung pada ingatan seseorang pada saat pengisian kuesioner. Suciati (2001) berpendapat bahwa tingkat pengetahuan berorientasi kepada kemampuan berfikir, mencakup kemampuan intelektual yang paling sederhana, yaitu mengingat, sampai dengan kemampuan untuk memecahkan suatu masalah yang menuntut individu untuk menghubungkan dan menggabungkan gagasan, metode atau prosedur yang sebelumnya dipelajari untuk memecahkan masalah tersebut melalui informasi dan ilmu pengetahuan. Hasil akhir akan 
terlihat dari skor yang diperoleh oleh peserta penyuluhan.

Pengetahuan tentang anemia harus diketahui siswi sejak dini mengingat saat ini banyak kasus anemia yang terjadi tidak hanya pada orang dewasa tetapi juga pada remaja sehingga pemerintah mencanangkan program pemberian tablet $\mathrm{Fe}$ kepada remaja, sayangnya program ini belum dilaksanakan secara menyeluruh. Karena itu peningkatan pengetahuan dan pemahaman tentang anemia melalui penyuluhan harus sering dilaksanakan.

Notoadmodjo (2007) mengemukakan bahwa pengetahuan terjadi setelah orang melakukan penginderaan terhadap suatu objek tertentu, pengetahuan bisa dipengaruhi oleh banyak hal. Lebih lanjut Notoadmojo menyatakan bahwa pengetahuan tersebut bisa didapat melalui panca indra manusia, yakni indra penglihatan, pendengaran, penciuman, rasa dan raba. Pengetahuan merupakan hasil dari apa yang didapatkan secara formal maupun informal.

Pendidikan sangat memengaruhi pengetahuan remaja. Kurangnya pengetahuan remaja putri tentang anemia juga bisa disebabkan kurangnya informasi yang didapatkan oleh remaja tersebut. Informasi yang ada saat ini belum sepenuhnya dapat diserap dan dipahami oleh remaja terutama yang tinggal diluar kota meskipun akses telekomunikasi sudah ada tetapi penggunaannya masih terbatas, hal ini akan menjadi lebih sulit apabila remaja lebih mengutamakan menggunakan akses telekomunikasi ke hal-hal yang sifatnya hiburan dibanding dengan informasi ilmu pengetahuan, sehingga masih ada remaja putri yang belum mengetahui apa itu anemia dan manfaat yang dapat diperoleh dengan mencegah anemia sedini mungkin, remaja putri harus memiliki pedoman dalam hidup bahwa pencegahan lebih baik dari pada pengobatan.

Adanya deteksi dini anemia melalui pemeriksaan $\mathrm{Hb}$ juga dapat membantu seseorang dalam mengenali gejala anemia yang terjadi. Pemeriksaan $\mathrm{Hb}$ secara rutin dapat membantu mencegah terjadinya kejadian anemia yang lebih luas, karena dengan mengetahui jumlah kadar $\mathrm{Hb}$ yang dimiliki seseorang dapat dilakukan penatalaksanaan lebih cepat untuk menghindari anemia. Sebagai contoh apabila seseorang yang diperiksa mendapati kadar $\mathrm{Hb}$ rendah maka dapat disarankan kepadanya untuk mengkonsumsi tablet $\mathrm{Fe}$ atau meningkatkan asupan makanan yang mengandung $\mathrm{Fe}$ dan vitamin $\mathrm{C}$ atau vitamin A, karena vitamin tersebut dapat membantu penyerapan $\mathrm{Fe}$ sehingga dapat mempercepat peningkatan kadar $\mathrm{Hb}$.

Berdasarkan hasil yang diperoleh dari pemeriksaan kadar $\mathrm{Hb}$ siswi yang ada di SMA N 1 Pancur Batu maka bagi siswi yang kadar $\mathrm{Hb}$ di bawah normal $(<12 \mathrm{mg} / \mathrm{dl})$ diberikan tablet $\mathrm{Fe}$ kombinasi vitamin untuk meningkatkan kadar $\mathrm{Hb}$ nya sehingga anemia bisa diatasi.

Ketika dilakukan tanya jawab dengan siswi yang mempunyai kadar $\mathrm{Hb}$ di bawah normal didapatkan jawaban bahwa mereka rata-rata kurang atau tidak suka mengkonsumsi sayur dan buah sehari-hari walaupun orang tua 
telah menyediakannya dalam menú makan sehari-hari., sering terlambat makan atau makan tidak teratur, selain itu konsumsi susu juga jarang dilakukan. Hasil penelitian menyatakan bahwa beberapa faktor yang dapat memengaruhi kadar $\mathrm{Hb}$ yang rendah pada remaja diantaranya: kehilangan darah yang disebabkan oleh menstruasi, kurangnya $\mathrm{Fe}$ dalam makanan yang dikonsumsi, pola hidup remaja putri berubah dari yang semula serba teratur menjadi kurang teratur, misalnya sering terlambat makan atau kurang tidur dan ketidakseimbangan antara asupan gizi dan aktifitas yang dilakukan (Basith et al., (2017) ; Kaimudin et al., (2017) ; Listiana A, (2016). Kadar $\mathrm{Hb}$ yang rendah pada siswi di SMA N 1 Pancur Batu kemungkinan besar disebabkan karena ketidakseimbangan asupan gizi disamping karena adanya menstruasi setiap bulan.

Pada kegiatan pengabdian masyarakat ini kami hanya melakukan pemeriksaan kadar $\mathrm{Hb}$ untuk memantau secara dini kasus anemia pada remaja putri di SMA N 1 Pancur Batu. Dengan adanya pemeriksaan ini siswi dapat mengetahui kadar $\mathrm{Hb}$ mereka dan juga mengetahui bagaimana caranya untuk mendeteksi anemia secara dini, begitupun penyuluhan yang diberikan telah mampu meningkatkan pengetahuan siswa tentang anemia pada remaja. Pelatihan mengenai menú makanan sehat bagi remaja belum dapat dilakukan mengingat keterbatasan waktu pelaksanaan karena siswi yang ada di SMA N 1 Pancur Batu harus mengikuti jam belajar disekolahnya.

\section{Kesimpulan dan Saran}

Kegiatan edukasi berupa penyuluhan tentang anemia pada remaja dapat meningkatkan pengetahuan siswi yang terlihat dari perubahan hasil pre test dan post test yang telah dilakukan. Pemeriksaan kadar $\mathrm{Hb}$ sebagai bentuk deteksi dini yang dilakukan juga dapat menjaring siswi yang mengalami anemia sehingga dapat dilakukan tindakan penanganan berupa pemberian tablet Fe.

Diharapkan kepada siswi agar lebih aktif dalam mencari informasi yang berkaitan dengan anemia dan penatalaksanaanya begitu juga dengan pihak sekolah untuk tetap membuat jadwal kegiatan untuk sosialisasi kesehatan dan memantau kesehatan siswi melalui UKS.

Diharapkan adanya kerjasama lintas sektoral baik dinas pendidikan dan dinas kesehatan untuk melakukan program edukasi gizi remaja melalui kegiatan deteksi anemia remaja dan makan bersama dengan menu berbahan makanan lokal di wilayah sekolah sehingga derajat kesehatan siswi dapat maksimal.

\section{Daftar Pustaka}

Adriani, M., \& Wirjatmadi, B. (2016). Pengantar Gizi Masyarakat. In Prenadamedia.

Ayu Dwi Putri Rusman. (2018). Pola Makan dan Kejadian Anemia pada Mahasiswi yang Tinggal di Kos-KosaN. Jurnal Ilmiah Manusia Dan Kesehatan, 1(2). https://doi.org/10.31850/makes.v1i2.141

Basith, A., Agustina, R., \& Diani, N. (2017). FaktorFaktor yang Berhubungan dengan Kejadian Anemia pada Remaja Putri. Dunia Keperawatan, 5(1). https://doi.org/10.20527/dk.v5i1.3634

Crowe, T. (2012). Oxford Handbook of Nutrition and Dietetics. Second edition by Webster-Gandy J, Madden A and Holdsworth M. Oxford University Press, Oxford, UK, 2012, 816 pages, 
A \$57.95, ISBN 978-0199585823. Nutrition \& Dietetics, 69(4). https://doi.org/10.1111/17470080.12003

Egryani, N. P. R., Saktini, F., Puspitasari, \& Dewi, V. (2017). Pengaruh Penyuluhan Satu Lawan Satu Terhadap Pengetahuan Ibu Hamil Mengenai Anemia di Semarang. Diponegoro Medical Journal (Jurnal Kedokteran Diponegoro), 6(2).

Hastuty, Y. D., \& Khodijah, D. (2018). Analisis Pemberian Tablet $\mathrm{Fe}$ dengan Kombinasi Vitamin C dan Vitamin A Terhadap Anemia pada Siswi SMU di Kecamatan Medang Deras Kabupaten Batubara. Jurnal Ilmiah PANNMED (Pharmacist, Analyst, Nurse, Nutrition, Midwivery, Environment, Dentist), 12(2). https://doi.org/10.36911/pannmed.v12i2.17

Hidayati, K. B., \& Farid, M. (2016). Konsep Diri, Adversity Quotient dan Penyesuaian Diri pada Remaja. Persona:Jurnal Psikologi Indonesia, 5(02).

https://doi.org/10.30996/persona.v5i02.730

Hoffbrand V (2013). Kapita Selekta Hematologi (terjemahan). In Edisi ke-6, Jakarta (pp. 20-45)

Kaimudin, N., Lestari, H., \& Afa, J. (2017). Skrining dan Determinan Kejadian Anemia Pada Remaja Putri SMA Negeri 3 Kendari Tahun 2017. Jurnal Ilmiah Mahasiswa Kesehatan Masyarakat Unsyiah, 2(6). https://doi.org/10.37887/jimkesmas

Kemenkes. (2018). Hasil Utama Riset Kesehata Dasar (RISKESDAS). Journal of Physics A: Mathematical and Theoretical, 44(8), 1-200. https://doi.org/10.1088/1751-8113/44/8/085201
Listiana A. (2016). Analisis faktor-faktor yang berhubungan dengan kejadian anemia gizi besi pada remaja putri di smkn 1 terbanggi besar lampung tengah. Jurnal Kesehatan, VII(3).

Masthalina, H., Laraeni, Y., \& Dahlia, Y. P. (2015). Pola konsumsi (faktor inhibitor dan enhancer $\mathrm{Fe})$ terhadap status anemia remaja putri. Jurnal Kesehatan Masyarakat, 11(1), 80-86. https://doi.org/ISSN 1858-1196

Maulana, H. (n.d.). Promosi Kesehatan. Jakarta: $E G C$;

Notoadmodjo. (2007). Ilmu Kesehatan Masyarakat dan Seni, PT. Rineka Cipta, Jakarta.

Permaesih, D., Ernawati, F., Ridwan, E., . S., \& Saidin, S. (2011). Pengaruh Suplementasi Zat Gizi Mikro Terhadap Status Besi Dan Status Vitamin A Pada Siswa Sltp. Gizi Indonesia, 1(34).

Suciati. (2001). Teori Belajar dan Motivasi. PAUPPAI Universitas Terbuka.

Utama, T. A., Listiana, N., \& Susanti, D. (2013). Perbandingan Zat Besi dengan dan Tanpa Vitamin C terhadap Kadar Hemoglobin Wanita Usia Subur. Jurnal Kesehatan Masyarakat Nasional, 7, 344-348.

WHO. (2015). The global prevalence of anaemia in 2011. Geneva: World Health Organization. In WHO Report. 